\title{
Influence of Breed on Forage Intake of Range Beef Cows
}

\author{
S.L. KRONBERG, K.M. HAVSTAD, E.L. AYERS AND D.E. DOORNBOS
}

\section{Abstract}

We estimated forage intake of Hereford (HH) and $75 \%$ Simmental-25\% Hereford (3S1H) cows graxing in northeentral Montana during the summer graxing season of 1982. Cows ranged freely over a 81-ha pasture of rough fescue (Festuca scabrella)dominated rangeland. Intake was estimated for 6 lactating (March calved) and 6 nonlactating cows of each breed type in June, July, August, and September, 1982. Fecal output of dry cows was measured with total fecal collections and was also estimated with the chromic oxide dilution technique. Only the chromic oxide technique was used for lactating cows. Three to 4 esophageal-fistulated cows of each breed type were used for collection of dietary material suitable for in vitro digestibility analysis. Organic matter intake (as a percentage of body weight per day, $\% \mathrm{BW} / \mathrm{D}$ ) of nonlactating $\mathrm{HH}$ and $3 S 1 \mathrm{H}$ cows did not differ $(P \geq 10$ ), averaging $1.3 \% \mathrm{BW} / \mathrm{d}$ (using total fecal collection estimates). Chromic oxide derived forage intake estimates were $15 \%$ higher $(P<.10)$ than total feeal collection estimates. Breeds responded similarly $(P 41 / 1.10)$ to both fecal output estimation techniques. Forage intake estimates for lactating cows were adjusted for this overestimation, and lactating 3S1H cows consumed more $(P<.10)$ forage than lactating HH cows $(1.9$ vs. $1.7 \% \mathrm{BW} / \mathrm{d}$, and $10.9 \mathrm{vs.} 7.8 \mathrm{~kg} / \mathrm{d}$, respectively).

Forage intake has been estimated for many domestic and wild ruminants with varying nutritional requirements. However, des pite the economic importance of the lactating range beef cow, estimates of forage intake for these animals are rare (Van Dyne et al. 1980). In addition, characteristics of different breed types influencing forage intake are poorly understood. We estimated forage intake of free-ranging lactating and nonlactating Hereford (HH) and 75\% Simmental-25\% Hereford (3S1H) cows. Hereford cows had been characterized as a smaller body weight, lower milk production breed type, and $3 \mathrm{~S} 1 \mathrm{H}$ cows had larger body weight and higher milk production characteristics (Casebolt et al. 1983, Kress et al. 1984). These differences allowed us to assess the effect of distinctly different breed types on forage intake under rangeland conditions.

\section{Materials and Methods}

Field work for this study was conducted in an 81-ha pasture on the northwestern slopes of the Bearpaw Mountains in north central Montana. The pasture was a portion of land used by Montana's Northern Agricultural Research Center as summer pasture for a beef cow herd. Vegetation of the pasture is a rough fescue (Festuca scabrella), Idaho fescue (Festuca idahoensis) and bluebunch wheatgrass (Agropyron spicatum)-dominated grassland (15, 10, and $2 \%$ composition of vegetation, respectively) with interspersed areas of ponderosa pine (Pinus ponderosa) overstory. Average annual precipitation of the study site is $482 \mathrm{~mm}$ (USDA-SCS, 1976). This study site is typical of foothill rangeland in north central Montana.

Forage intake was estimated using the equation: organic matter intake = total fecal organic matter output $/$ l-dietary organic matter digestibility. Daily organic matter intake was expressed as a percentage of body weight (\% BW/d) and as the total quantity of

\footnotetext{
Authors are former graduate research assistant, associate professor, research associate, and assistant professor, Animal and Range Sciences Department, Montana State University, Bozeman 59717. D.E. Doornbos is located at the Northern Agricultual Research Center, Havre, Mont. 59501. S.L. Kronberg is currently graduate research assistant at the Range Science Department. UMC 52, Utah State University, Logan 84322.

This manuscript was approved by the Director of the Montana Agricultural Experiment Station as Journal Paper No. J-1471.

Manuscript accepted 13 January 1986.
}

forage consumed per day $(\mathrm{kg} / \mathrm{d})$. Body weights were determined after a 14-h fast before each fecal collection period.

Total fecal organic matter output of nonlactating cows was estimated with total fecal collections and the chromic oxide dilution technique. Total fecal collections were made for a $96-\mathrm{h}$ period once/month. We collected feces from 6 cows of each breed during June, July, August, and September 1982 using fecal apparatus described by Kartchner and Rittenhouse (1979). Lactating and nonlactating cows were handled and pastured together. Cows were gathered twice daily at approximately 12 -h intervals to change fecal bags; collected fecal material was sampled and frozen at $0^{\circ} \mathrm{C}$. These samples were later analyzed for dry matter and organic matter (AOAC 1970).

Six days before each total fecal collection period, each cow (lactating and nonlactating) was dosed daily, at approximately 1800 hours, with $10 \mathrm{~g}$ of chromic oxide powder contained in a gelatin capsule. Fecal samples were taken from the rectum of each cow from day 7 through day 10 . Subsequently, these samples were dried at $40^{\circ} \mathrm{C}$, ground through a $1-\mathrm{mm}$ screen and analyzed for chromic oxide content using a colorimetric procedure (Bolin et al. 1952). The percentage of chromic oxide in a fecal grab sample was entered into the equation: fecal output $/$ day $=$ quantity of chromic oxide fed/day $\times 100 /$ percentage of chromic oxide in the grab sample. We converted to an organic matter basis for comparison with fecal output estimates from total fecal collection. Dietary organic matter digestibility was determined on extrusa material using Barne's modification of the Tilley and Terry in vitro technique (Harris 1970). We obtained rumen fluid inoculum from a rumen-cannulated cow fed grass hay (Bromus inermis and Phleum pratense) (IVOMD $=55 \%$ ) ad libitum. This hay served as the standard. Extrusa samples were collected from cows of both breeds equipped with esophageal fistulas. We collected extrusa approximately 4 times during the monthly 10-day period of chromic oxide administration. Collections were made during the morning following overnight fasting of the animal.

Data on forage intake estimation and fecal output estimating techniques were analyzed separately by split-plot analysis of variance procedures including breed as the whole unit and month as the subunit. The use of month as a subunit reflected monthly differences in extrusa IVOMD. We used multiple regression to examine factors influencing intake of lactating cows. The regression model included breed and month as fixed sources of variation.

\section{Results and Discussion}

There were no differences in average seasonal intake estimates (\% BW/ d) between the 2 breed types of nonlactating cows $(P<.10$, Table 1). Daily total forage consumption different $(P<.10)$ between breeds, with the $83 \mathrm{~kg}$ heavier crossbred cows consuming $1.1 \mathrm{~kg} / \mathrm{d}$ more organic matter than the Herefords. Estimates of fecal outputs based on chromic oxide were $15 \%$ higher $(P<.10)$ than those obtained from total fecal collection. Chromic oxide-derived estimates have varied from $31 \%$ to $87 \%$, but most estimates tend to be approximately $20 \%$ higher than measured values (Raleigh et al. $1980)$. We observed no significant differences $(P \geq 10)$ in digestibility between extrusa collections from Hereford and crossbred cows. Consequently, digestibility values for extrusa collections from both breed types were combined to make 1 value for each collection period. Monthly changes in IVOMD reflected the variable growth of forage species.

For lactating cows, breed type influenced intake as a percentage of body weight $(P<.10$, Table 2$)$. These differences were magnified 
Table 1. Body weight, daily intake and feeal output, and diet digestiblity of nonlactating cows of two breed types (19s2).

\begin{tabular}{|c|c|c|c|c|c|c|c|c|c|}
\hline \multirow[b]{2}{*}{ Month } & \multicolumn{2}{|c|}{ Body Weight } & \multicolumn{4}{|c|}{ Daily intake } & \multicolumn{2}{|c|}{ Fecal Output } & \multirow{2}{*}{$\begin{array}{l}\text { Diet digest- } \\
\text { ibility }\end{array}$} \\
\hline & HH & $3 \mathrm{~S} 1 \mathrm{H}$ & $\mathbf{H H}$ & $3 \mathrm{SIH}$ & $\mathbf{H H}$ & $3 \mathrm{~S} 1 \mathrm{H}$ & $\mathbf{H H}$ & $3 \mathrm{~S} 1 \mathrm{H}$ & \\
\hline & & -2 & 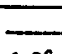 & & & $\overline{a n d}$ & 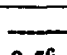 & & $-\%$ \\
\hline $\begin{array}{l}\text { June } \\
\text { July } \\
\text { August } \\
\text { September } \\
\text { AVERAGE }\end{array}$ & $\begin{array}{l}523^{c} \\
553^{e} \\
569^{c} \\
579^{c} \\
556^{e}\end{array}$ & $\begin{array}{l}592^{d} \\
633^{d} \\
661 a^{d} \\
669^{d} \\
639^{d}\end{array}$ & $\begin{array}{l}1.3^{\mathrm{c}} \\
1.2^{\mathrm{c}} \\
1.2^{\mathrm{c}} \\
1.5^{\mathrm{c}} \\
1.3^{\mathrm{c}}\end{array}$ & $\begin{array}{l}1.4^{\mathrm{c}} \\
1.2^{\mathrm{c}} \\
1.1^{\mathrm{c}} \\
1.3^{\mathrm{d}} \\
1.3^{\mathrm{c}}\end{array}$ & $\begin{array}{l}6.8^{c} \\
6.6^{c} \\
6.8^{c} \\
8.7^{c} \\
7.2^{c}\end{array}$ & $\begin{array}{l}8.3^{d} \\
7.6^{c} \\
7.3^{c} \\
8.7^{c} \\
8.3^{d}\end{array}$ & $\begin{array}{l}0.5^{\mathfrak{c}} \\
0.7^{\mathrm{c}} \\
0.7^{\mathrm{c}} \\
0.7^{\mathrm{c}} \\
0.7^{\mathrm{c}}\end{array}$ & $\begin{array}{l}0.6^{\mathrm{e}} \\
0.6^{\mathrm{c}} \\
0.7^{\mathrm{c}} \\
0.6^{\mathrm{d}} \\
0.6^{\mathrm{c}}\end{array}$ & $\begin{array}{l}59 \\
45 \\
41 \\
55 \\
50\end{array}$ \\
\hline
\end{tabular}

Organic matter basis.

Percentage of body weight.

c.d Means within a factor and row with different superscripts differ $(\mathbb{P}<.10)$.

Table 2. Body weights, daily intake, and dally fecal output of hetating cows of two breed types (1982).

\begin{tabular}{|c|c|c|c|c|c|c|c|c|}
\hline \multirow[b]{2}{*}{ Month } & \multicolumn{2}{|c|}{ Body Weight } & \multicolumn{4}{|c|}{ Daily Intaken } & \multicolumn{2}{|c|}{ Fecal Output ${ }^{*}$} \\
\hline & HH & $3 \mathrm{~S} 1 \mathrm{H}$ & HH & 3S1H & HH & $3 \mathrm{~S} 1 \mathrm{H}$ & HH & 3SIH \\
\hline \multirow{6}{*}{$\begin{array}{l}\text { June } \\
\text { July } \\
\text { August } \\
\text { September } \\
\text { AVERAGE }\end{array}$} & & & & & & & & \\
\hline & $433^{c}$ & $564^{d}$ & $1.9^{\mathrm{c}}$ & $2.2^{\mathrm{d}}$ & $8.2^{c}$ & $12.4^{\mathrm{d}}$ & $0.8^{c}$ & $0.9^{c}$ \\
\hline & $457^{c}$ & $557^{d}$ & $1.7^{\mathrm{c}}$ & $2.0^{\mathrm{d}}$ & $7.8^{\mathrm{c}}$ & $11.1^{\mathrm{d}}$ & $0.8^{c}$ & $0.9^{c}$ \\
\hline & $474^{c}$ & $586^{\mathrm{d}}$ & $1.6^{\mathrm{e}}$ & $1.4^{\mathrm{c}}$ & $7.6^{\mathrm{c}}$ & $8.2^{\mathrm{c}}$ & $0.9^{c}$ & $0.8^{c}$ \\
\hline & $475^{\mathrm{c}}$ & $586^{\mathrm{d}}$ & $1.7^{\mathrm{c}}$ & $2.1^{\mathrm{d}}$ & $8.1^{\mathrm{c}}$ & $12.3^{\mathrm{d}}$ & $0.8^{c}$ & $0.9^{d}$ \\
\hline & $460^{c}$ & $573^{d}$ & $1.7^{\mathrm{c}}$ & $1.9^{\mathrm{d}}$ & $7.8^{\mathrm{c}}$ & $10.9^{d}$ & $0.8^{c}$ & $0.9^{d}$ \\
\hline
\end{tabular}

Organic matter basis.

bercentage of body weight.

c,d Means within a factor and row with different superscripts differ $(P<.10)$.

when examining the total forage consumed per day. Hereford cows consumed $28 \%$ less forage $(P<.10)$ than the crossbred cows. The forage intake estimates for lactating cows were adjusted for the $15 \%$ overestimation of fecal output obtained by the chromic oxide technique based upon analysis of the fecal data obtained from nonlactating cows. This overestimation was consistent for all fecal collection periods. Values reported in the literature for lactating cows range from 1.6 to $3.2 \% \mathrm{BW} / \mathrm{d}$ (Table 3). Differences among these tabulated estimates reflect the accuracy of techniques used as well as differences in intake of dissimilar cows in unlike environments.

Lactating Hereford and crossbred cows consumed about 23 to $39 \%$ more forage, respectively, than their nonlactating counterparts. This resembles reported 25 to $35 \%$ increases in intake asso-

Table 3. Literature information on lactation status, milk production, body weight and forage intake of free-roaming cows.

\begin{tabular}{|c|c|c|c|c|c|c|c|}
\hline Reference & $\begin{array}{l}\text { Type of } \\
\text { pasture }\end{array}$ & $\begin{array}{l}\text { Breed } \\
\text { of cow }\end{array}$ & $\begin{array}{l}\text { Lactational } \\
\text { status }\end{array}$ & $\begin{array}{l}\text { Milk production } \\
\text { (kg/day) }\end{array}$ & $\begin{array}{l}\text { Body weight } \\
\text { (kg) }\end{array}$ & $\begin{array}{l}\text { Forage intake } \\
\text { (\% body weight) }\end{array}$ & $\begin{array}{l}\text { Basis of } \\
\text { measurement }\end{array}$ \\
\hline $\begin{array}{l}\text { Elliot \& Fokkema } \\
\text { (1961) }\end{array}$ & veld grassland & $\begin{array}{l}\text { Afrikander } \\
\text { Mashona } \\
\text { Afrikander } \\
\text { Mashona }\end{array}$ & $\begin{array}{l}\text { dry } \\
\text { dry } \\
\text { lactating } \\
\text { lactating }\end{array}$ & $\begin{array}{l}- \\
\overline{-}\end{array}$ & $\begin{array}{l}533 \\
318 \\
408 \\
295\end{array}$ & $\begin{array}{ll}1.5 & \text { (OMB) } \\
1.3 & \text { (OMB) } \\
2.5 & \text { (OMB) } \\
2.6 & \text { (OMB) }\end{array}$ & TC/LR \\
\hline Hills (1968) & $\begin{array}{l}\text { semidesert } \\
\text { grassland }\end{array}$ & $\begin{array}{l}\text { Hereford \& } \\
\text { Santa Gertrudis }\end{array}$ & - & - & $\begin{array}{l}436- \\
439\end{array}$ & ${ }^{1.7-}$ (DMB) & $\mathrm{LR} / \mathrm{Cr}_{2} \mathrm{O}_{3}$ \\
\hline $\begin{array}{l}\text { Holloway et al. } \\
\text { (1979) }\end{array}$ & tall fescue & Angus & lactating & 8.5 & 458 & 2.0 (DMB) & $\mathrm{Cr}_{2} \mathrm{O} 3 / \mathrm{ADL}$ \\
\hline $\begin{array}{l}\text { Holloway et at. } \\
\text { (1979) }\end{array}$ & $\begin{array}{l}\text { tall fescue- } \\
\text { legume mix }\end{array}$ & Angus & lactating & 8.3 & 472 & 2.1 (DMB) & $\mathrm{Cr}_{2} \mathrm{O}^{3} / \mathrm{ADL}$ \\
\hline $\begin{array}{l}\text { Holmes \& Osman } \\
(1960)\end{array}$ & $\begin{array}{l}\text { ryegrass- } \\
\text { clover mix }\end{array}$ & Ayrshire & lactating & 14.4 & 513 & 2.3 (OMB) & $\mathrm{FNI} / \mathrm{Cr}_{2} \mathrm{O}_{3}$ \\
\hline $\begin{array}{l}\text { Holmes et al. } \\
\text { (1961) }\end{array}$ & $\begin{array}{l}\text { ryegrass- } \\
\text { clover mix }\end{array}$ & Ayrshire & dry & - & 537 & 1.8 (OMB) & $\mathrm{FNI} / \mathrm{Cr}_{2} \mathrm{O}_{3}$ \\
\hline $\begin{array}{l}\text { Kartchner } \\
\text { (1975) }\end{array}$ & $\begin{array}{l}\text { crested } \\
\text { wheatgrass }\end{array}$ & - & lactating & - & $\begin{array}{l}523- \\
615\end{array}$ & ${ }^{1.6-}$ (DMB) & TC/IVDMD \\
\hline $\begin{array}{l}\text { Streeter et al. } \\
\text { (1974) }\end{array}$ & native meadow & $\begin{array}{l}\text { Brown Swiss } \\
\text { Charolais } \times \text { Angus } \\
\text { Hereford }\end{array}$ & $\begin{array}{l}\text { lactating } \\
\text { lactating } \\
\text { lactating }\end{array}$ & $\begin{array}{r}10.3 \\
7.5 \\
6.0\end{array}$ & $\begin{array}{l}473 \\
374 \\
363\end{array}$ & $\begin{array}{ll}3.1 & \text { (DMB) } \\
3.2 & \text { (DMB) } \\
2.8 & \text { (DMB) }\end{array}$ & $\mathrm{Cr}_{2} \mathrm{O}_{3} / \mathrm{IVCWC}$ \\
\hline $\begin{array}{l}\text { Stehr \& Kirchgessner } \\
\text { (1976) }\end{array}$ & - & Simmental & lactating & 17.5 & 675 & 1.6 (OMB) & Agronomic \\
\hline
\end{tabular}


ciated with lactation (Elliot et al. 1961, Field 1966, Jones et al. 1965). In attempting to explain the increased forage intake of the lactating cow, Smith and Baldwin (1974) observed hypertrophy of the alimentary tract in lactating cows and Campling (1970) suggested that this occurs with endocrine changes associated with lactation.

When examining factors of the statistical model, lactation status was the only significant factor explaining differences in intake between nonlactating and lactating cows. When month and breed type were considered as factors for explaining variation in intake of lactating cows, only the breed type was significant. This suggests that the supposed milk production differences between $\mathrm{HH}$ and 3S1H cows may be the most important factor in explaining their intake differences. With the large metabolizable energy requirement for milk production, it is possible that breed differences in intake seen in this study are partially due to the greater energy demand of lactation resulting in increased forage consumption during the summer grazing season. A related study, at the Northern Agricultural Research Center, estimated milk production (weigh-suckle-weigh technique) of $\mathrm{HH}$ and $3 \mathrm{~S} 1 \mathrm{H}$ cows through the 1982 summer grazing season (Casebolt et al. 1983). This study concluded that $\mathrm{HH}$ cows produced approximately $11,8,6$, and 5 $\mathrm{kg} / \mathrm{d}$ during June, July, August, and September, respectively. The $3 \mathrm{~S} 1 \mathrm{H}$ cows produced approximately $12,11,10$, and $9 \mathrm{~kg} / \mathrm{d}$ during June, July, August, and September, respectively. The energy cost for a cow to produce milk is approximately 1 Mcal of metabolizable energy $/ \mathrm{kg}$ of milk produced (Blaxter 1962, NRC 1984). The additional energy requirements (Mcal ME) for milk production are approximated by these milk production values. McClymont (1967) suggested that total energy demand is the primary facilitory stimulus for phagic behavior. As the cow's energy demand attributable to lactation rises, forage intake should also increase.

For diets of low quality, additional forage intake to meet energy demands of lactation may not be possible due to limitations of the physical capacity of the reticulorumen and the slower passage rate of the digesta associated with lower quality forages (Conrad et al. 1964). Using IVOMD as an index to forage quality the diets of cows in our study could be regarded as moderate quality. The significance of breed as a factor explaining the variation in intake of lactating cows may lessen with diets of lower quality. Animalrelated factors, such as cow body condition, calf sex, age, and size, and physiological and digestive system parameters may also influence the breed differences in intake reported in our study. Ferrell and Jenkins (1985) have emphasized the importance of quantifying the input components (including intake) relative to different cow types. Further studies will be required to quantify the influence of animal and forage factors upon the forage intake of different cow breeds grazing in a rangeland environment.

\section{Literature Cited}

AOAC. 1970. Official methods of analysis (11th Ed.). Association of Official Agr. Chem., Washington, D.C.

Blaxter, K.L. 1962. The energy metabolism of ruminants. Charles C. Thomas Pub.

Bolin, D.W., R.P. Kint, and E.W. Klosterman. 1952. A simplified method for the determination of chromic oxide when used as an index substance. Science 116:634.

Campling, R.C. 1970. Physical regulation of voluntary intake. p. 266. In: A.T. Phillipson (Ed.). Physiology and Metabolism in the Ruminant. Oriel Press.

Casebolt, D.G., D.D. Kress, D.C. Anderson, and D.E. Doornbos. 1983. Lactation curves and milk production in beef cattle with varying degrees of crossbred influence. Proc. West. Sec. Amer. Soc. Anim. Sci. 34:37.
Connd, H.R., A.D. Pratt, and J.W. Hibbs. 1964. Regulation of feed intake in dairy cows. 1 . Change in importance of physical and physiological factors with increasing digestibility. J. Dairy Sci. 47:54.

Elliot, R.C., and K. Folkema. 1961. Herbage consumption studies on beef cattle. I. Intake studies on Afrikander and Mashona cows on veld grazing 1958-59. Rhodesian Agr. J. 58:49.

Elliot, R.C., K. Fokkema, and C.H. French. 1961. Herbage consumption studies on beef cattle II. Intake studies on Afrikander and Mashona cows on veld grazing 1959-60. Rhodesian Agr. J. 58:124.

Ferrell, C.L., and T.G. Jenkins. 1985. Cow type and the nutritional environment: nutritional aspects. J. Anim. Sci. 61:725.

Fleld, A.C. 1966. The effect of lactation on the intake of dry matter, magnesium, calcium, and potassium by grazing cows. Proc. X. Internat. Grassl. Congr.

Harris, L.E. 1970. Nutrition research techniques for domestic and wild animals. Vol. I. L.E. Harris Pub., Logan, Utah.

Hills, J.M. 1968. Intake and digestibility of range forage by Hereford and Santa Gertrudes cows. MS Thesis. New Mexico State Univ., Las Cruces.

Holloway, J.W., W.T. Butts, J.D. Beaty, J.T. Hopper, and N.S. Hall. 1979. Forage intake and performance of lactating beef cows grazing high or low quality pastures. J. Anim. Sci. 48:692.

Holmes, W., J.C.W. Jones, and R.M. Drake-Brockman. 1961. The feed intake of grazing cattle. II. The influence of size of animal on feed intake. Anim. Prod. 3:251.

Holmes, W., and H.S. Omman. 1960. The feed intake of grazing cattle. I. Feed intake of dairy cows on strip and free grazing. Anim. Prod. 2:131.

Jones, J.G.W., R.M. Drake-Brockman, and W. Holmes. 1965. The feed intake of grazing cattle. IIl. The influence of level of milk yield. Anim. Prod. 7:141.

Kartchner, R.J. 1975. Forage intake and related performances criteria of spring and fall calving cow-calf pairs on summer range. Ph.D. Thesis, Oregon State Univ., Univ. Microfilms, Ann Arbor, Mich. (Diss. Abstr. 35:5730).

Kartchner, R.J., and L.R. Rittenhouse. 1979. A feces-urine separator for making total fecal collections from female bovine. J. Range Manage. 32:404.

Kress, D.D., D.E. Doombon, D.C. Anderson, and D.D. Trowbridge. 1984. Productivity of two-year-old straightbred and crossbred dams. II. Dam performance and overall productivity. Proc. West. Sec. Amer. Soc. Anim. Sci. 35:90.

McClymont, G.L. 1967. Selectivity and intake in the grazing ruminant. p. 129-137. In: C.F. Code (Ed.) Volume I. Control of Food and Water Intake. Section 6: Alimentary Canal. Handbook of Physiology. Amer. Phys. Soc., Washington, D.C.

NRC. 1984. Nutrient requirements of beef cattle. Sixth Revised Ed. National Academy of Sciences - National Research Council, Washington D.C.

Raleigh, R.J., J.R. Kartehner, and L.R. Rittenhouse. 1980. Chromic oxide in range nutrition studies. Oregon State Univ. Agr. Exp. Sta. Bull. 641. Corvallis.

Smith, N.E., and R.L. Baldwin. 1974. Effects of breed, pregnancy and lactation on weight of organs and tissues in dairy cattle. J. Dairy Sci. 57:1055.

Stehr, W., and M. Kirchgeaner. 1976. The relationship between the intake of herbage grazed by dairy cows and its digestibility. Anim. Sci. Tech. 1:53.

Streeter, C.L., C.B. Rumber, T.H. Hall, and E.G. Slemer. 1974. Meadow forage quality, intake and milk production of cows. J. Range Manage. 27:133.

USDA-SCS. 1976. Climax vegetation of Montana: Based on soils and climate. United States Department of Agriculture - Soil Conservtion Service, Bozeman, Mont.

Van Dyne, G.M., N.R. Brockington, Z. Szoet, J. Duek, and C.A. Ribic. 1980. Large herbivore sybsystem. p. 260-420. In: A.J. Breymeryer and G.M. Van Dyne (Ed.) Grassland System Analysis and Man. Internat. Bio. Pro. 19, Cambridge Univ. Press. London. 